Towards interprofessionality in developing family mediation in Finland

\title{
Bergman-Pyykkönen, Marina
}

2017-01-12

Bergman-Pyykkönen , M 2017 , ' Towards interprofessionality in developing family mediation

in Finland ' , Social work education , vol. 36 , no. 5 , pp. 575-590 . https://doi.org/10.1080/02615479.2016.1259403

http://hdl.handle.net/10138/233764

https://doi.org/10.1080/02615479.2016.1259403

acceptedVersion

Downloaded from Helda, University of Helsinki institutional repository.

This is an electronic reprint of the original article.

This reprint may differ from the original in pagination and typographic detail.

Please cite the original version. 
Post-print version of manuscript for article Marina Bergman-Pyykkönen (2017)

Towards interprofessionality in developing family mediation in Finland, Social Work

Education, 36:5, 575-590, DOI:10.1080/02615479.2016.1259403

\title{
TOWARDS INTERPROFESSIONALITY IN DEVELOPING FAMILY MEDIATION IN FINLAND
}

\author{
Marina Bergman-Pyykkönen
}

PhD Researcher, Department of Social Work, University of Helsinki, Finland and Researcher-Interventionist of the Project FASPER

\section{marina.bergman@helsinki.fi}

Collaboration crossing professional and organizational boundaries is promoted, but also considered difficult and uncalled for. The aim of this study is to advance the comprehension of inter-professional collaboration on boundaries as a resource for learning and change. I examine and trace the initial shapes of interprofessionality and learning in two separate learning networks of a project researching, developing and learning family mediation in Finland. The naturally occurring data consists of transcribed audio-taped talk between practitioners (e.g. social workers, family counsellors, psychologists and judges) at the beginning of their collaborative work. The qualitative analysis detected communicative patterns, disruptions and dialogical learning mechanisms. The results interpreted through Cultural-Historical Activity Theory show that although the two quite similarly composed learning networks were given the same tasks, they differed on emerging learning mechanisms and unfolding dialogues. If collaboration is intended to be inter-professional and lead to change, there is a need to actively create shared tools, such as models, that enable transformative dialogue. For social work education inter-professional collaboration poses a challenge: how can education concurrently promote both learning the boundaries of social work and learning how to inter-professionally cross them?

Keywords: boundary crossing, dialogical learning mechanisms, discursive tools, inter-professional collaboration, polycontextual expertise 


\section{Introduction}

Work that crosses professional boundaries is nothing new, and calls for multi- or interprofessional collaboration have been vigorously promoted, as McLaughlin (2013) noted earlier in his critical commentary. Nevertheless, multi- or inter-professional work is not easy; if it were, social workers and other professions would have collaborated to a greater extent already (McLaughlin, 2013).

This study, intended to contribute to the ongoing discussion on the challenges of social work in multi-professional contexts, focuses on collaboration crossing both professional and organisational boundaries. This form of collaboration is considered crucial for creating new professional knowledge and practices, and entails potential for both learning and innovation (Akkerman \& Bakker, 2011). Participants negotiating and combining elements from different contexts in order to achieve a hybrid result engender polycontextual expertise (Y. Engeström, R. Engeström, \& Kärkkäinen, 1995). The purpose of my study is to advance the understanding of this form of expertise. I will trace and examine the first steps of collaboration in two multi-professional learning networks ${ }^{1}$ established to develop family mediation in Finland. I examine these steps from the point of view of both interprofessionality, which means crossing boundaries between different and possibly diverse professional knowledge, and learning. My approach to learning draws from the theory of expansive learning (Y. Engeström, 1987), with roots in Cultural-Historical Activity Theory (CHAT). This view emphasises communities as learners, transformation, and generation of everyday practices. Expansive learning is a collaborative endeavour of knowledge creation for expanding the understanding of the object of work (Y. Engeström \& Sannino, 2010). ${ }^{2}$ I ask: How do the first signs towards collaboration and interprofessionality emerge and what kind 
of learning can be identified in the discussions between the participants during the first meetings of the two studied learning networks?

In the analysis of learning I use as my analytical tool the features of four dialogical learning mechanisms (Akkerman \& Bakker, 2011). Based on my findings I argue that when collaboration aims at interprofessionality and change of practices, boundaries to be crossed must be recognised and shared tools for transformative dialogue created. Learning inter-professional collaboration and interprofessionality present a challenge for social work education.

\section{From Multi to Inter and Interprofessionality}

The use of the terms multi- and inter-professional collaboration causes confusion. In my research I understand the two as two distinct forms of working. In multi-professional collaboration, the participants represent different professional backgrounds and may work in the same community institutions, such as hospitals, or in different organizations. The multi-professional collaboration usually follows a traditional way of working and everyone acts according to the prevailing division of labour. (Couturier, Gagnon, Carrier, \& Etheridge, 2008; Edwards \& Kinti, 2010). Working in parallel guarantees the status quo and resembles co-operation between isolated professions (Wackerhausen, 2009).

When the participants in multi-professional and multi-organisational settings begin to contribute to a shared understanding of the object of work and work together on it, the collaboration becomes inter-professional. The true value of inter-professional collaboration resides in the meeting of different epistemologies and requires dialogue (Couturier et al., 2008). It expands both the knowledge and the skill levels of those working in the individual professions. Thus, for a collaboration to be not only multi-, but inter-professional, new knowledge that differs from the distinct specialist 
knowledge must emerge (Akkerman \& Bakker, 2011; Couturier et al., 2008). Therefore, in order to emphasize the meeting of diverse knowledge - the epistemological aspect of inter-professional collaboration-I introduce the term interprofessionality.

\section{Boundaries and Dialogical Learning Mechanisms}

In both multi- and inter-professional work, boundaries between professions, disciplines, practices and organisations become evident. Boundaries are social constructions and define who is included or excluded from interactions and which knowledge or meaning system is considered relevant (Edwards, 2010; Edwards \& Kinti, 2010). They are not barriers, however, but malleable and dynamic constructs or socio-cultural differences leading to discontinuity in action or interaction; thus, they can be learning resources and fruitful grounds for creating joint knowledge (Akkerman and Bakker, 2011).

The intersection of diverse practices is a vague middle ground: it belongs to all the intersecting practices, but is not defined by any one of them. This ambiguous nature of boundaries activates dialogue and negotiation of meaning that aims at diversity rather than homogeneity (Akkerman \& Bakker, 2011). It is challenging to encounter boundaries that are often unstable and uncomfortable (see Kerosuo, 2004, for boundary crossing in health care). Crossing boundaries requires special methods and tools to facilitate communication between the participants (R. Engeström, 2014a, Y. Engeström et al., 1995).

Akkerman and Bakker (2011) discerned four dialogical learning mechanisms that can take place on boundaries: Identification (identifying the diverse practices in relation to each other); Coordination (creating cooperative and routinized exchanges between practices); Reflection (expanding perspectives on the practices) and Transformation (collaborating on and co-developing new practices). ${ }^{3}$ Table 1 shows the dialogical learning mechanisms, their characteristic processes of boundary crossing and 
their relations to one another (adapted from Akkerman \& Bakker, 2011, 150-151). My interpretation is that Coordination typically emerges in multi-professional work, while Identification and Reflection are more common in the inter-professional form of collaboration; these two dialogical learning mechanisms are also conditional to Transformation. Thus, multi-professional collaboration involving Coordination as the only dialogical learning mechanism appears contrary to inter-professional collaboration involving Transformation. 
Table 1. Dialogical learning mechanisms, the characteristic processes of boundary crossing and the relationships among learning mechanisms (adapted from Akkerman \& Bakker, 2011, 150-151).

\begin{tabular}{|c|c|c|c|c|}
\hline $\begin{array}{c}\text { Dialogical } \\
\text { learning } \\
\text { mechanisms }\end{array}$ & $\begin{array}{c}\text { Characteristic } \\
\text { processes of } \\
\text { boundary } \\
\text { crossing }\end{array}$ & $\begin{array}{c}\text { In relation } \\
\text { to } \\
\text { boundaries }\end{array}$ & $\begin{array}{c}\text { In } \\
\text { relation } \\
\text { to } \\
\text { learning } \\
\text { processes }\end{array}$ & $\begin{array}{l}\text { Relating to } \\
\text { one another }\end{array}$ \\
\hline Identification & $\begin{array}{l}\text { Othering } \\
\text { Legitimating } \\
\text { coexistence }\end{array}$ & $\begin{array}{l}\text { Constructing, } \\
\text { reconstructing }\end{array}$ & $\begin{array}{l}\text { Meaning } \\
\text { oriented; } \\
\text { perspectives } \\
\text { and } \\
\text { identities at } \\
\text { stake }\end{array}$ & $\begin{array}{l}\text { Conditional for } \\
\text { Transformation }\end{array}$ \\
\hline Coordination & $\begin{array}{l}\text { Communicative } \\
\text { connection } \\
\text { Efforts of } \\
\text { translation } \\
\text { Increasing } \\
\text { boundary } \\
\text { permeability } \\
\text { Routinization }\end{array}$ & Transcending & $\begin{array}{l}\text { Practice- } \\
\text { based; } \\
\text { activity at } \\
\text { stake }\end{array}$ & $\begin{array}{l}\text { Opposite to } \\
\text { Transformation }\end{array}$ \\
\hline Reflection & $\begin{array}{l}\text { Perspective } \\
\text { making } \\
\text { Perspective } \\
\text { taking }\end{array}$ & Transcending & $\begin{array}{l}\text { Meaning } \\
\text { oriented; } \\
\text { perspectives } \\
\text { and } \\
\text { identities at } \\
\text { stake }\end{array}$ & $\begin{array}{l}\text { Conditional for } \\
\text { Transformation }\end{array}$ \\
\hline Transformation & $\begin{array}{l}\text { Confrontation } \\
\text { Recognizing } \\
\text { shared problem } \\
\text { space } \\
\text { Hybridization } \\
\text { Crystallization } \\
\text { Maintaining } \\
\text { uniqueness of } \\
\text { intersecting } \\
\text { practices } \\
\text { Continuous joint } \\
\text { work at the } \\
\text { boundary }\end{array}$ & Transcending & $\begin{array}{l}\text { Practice- } \\
\text { based; } \\
\text { activity at } \\
\text { stake }\end{array}$ & $\begin{array}{l}\text { Opposite to } \\
\text { Coordination }\end{array}$ \\
\hline
\end{tabular}


As many studies have shown, bringing together practitioners from different professional and organizational backgrounds to collaborate outside the shelters of their institutions is a special and demanding effort (Akkerman \& Bakker, 2011; Edwards \& Kinti, 2010). It contributes, however, to the emergence of a discursive space allowing for diversity in knowledge (Akkerman \& Bakker, 2011; Couturier et al., 2008; Y. Engeström et al., 1995; Klein, 1996). The present study advances the understanding of inter-professional collaboration. In order to search for and identify its initial shapes in my data, I examine the emergence of dialogical learning mechanisms during the first sessions of two separate multi-professional and multi-organizational learning networks.

Next I will introduce the context of my study: the project Fasper that researched and developed family mediation in Finland during 2009-2014. ${ }^{4}$

\section{The context: Family Mediation Activity and the Project Fasper}

Since the 1980 s, divorcing ${ }^{5}$ parents have been able to request a family mediator to help them resolve their conflicts and maintain responsible co-parenting. Family mediation is a statutory municipal social service and the task is often assigned to social workers or psychologists. These professionals work on the basis of their professional knowledge and skills as there is no formal family mediation education available in Finland. The family mediation service is poorly developed and relatively unknown to both families and practitioners (Haavisto, Bergman-Pyykkönen, \& Karvinen-Niinikoski, 2014; Julkunen \& Karvinen-Niinikoski, 2014).

Divorce is a crisis that concerns many life aspects and the parents tend to seek help from all available services. Unresolved parental conflicts endanger child development (see McIntosh, 2003) and the public costs of custody proceedings in Finland are extremely high (Hämäläinen, 2012). The practitioners' efforts to assist the parents may escalate conflicts instead of decreasing or solving them (Mattila-Aalto, 
Bergman-Pyykkönen, Haavisto, \& Karvinen-Niinikoski, 2012). This complex situation resulted in the initiation of Fasper. (Haavisto et al., 2014; Julkunen \& KarvinenNiinikoski, 2014).

Fasper aimed at knowledge production, transformative learning and creation of new practices and the project was built on the principles of Developmental Work Research (DWR), a methodology elaborated along with the theory of expansive learning (Y. Engeström, 1987). DWR aims “.. . to enable workers to become conscious subjects of their own learning activity and to combine independent learning activity with work" (R. Engeström, 2009, 257). From this aim an ethical demand arise as well: every participant's reflections and professional expertise are of genuine interest and are brought forward to the advantage of both the learners and the activity they develop (R. Engeström, 2009). Thus, Fasper served as post-professional education for the participating social workers and other practitioners; the participants learned both family mediation skills and inter-professional collaboration.

In DWR, researcher-interventionists guide a community in its effort to develop and transform practices (Y. Engeström \& Sannino, 2010). Following the cycle of expansive learning ${ }^{6}$ understood as construction and resolution of successively evolving contradictions, learning becomes more than the acquisition of knowledge or learning by participating. The learners construct together their interpretations of events by searching for new meanings, reinterpreting phenomena and creating new knowledge, and put the ideas into action; they apprehend something that is not yet there (Y. Engeström \& Sannino, 2010; Paavola, Lipponen \& Hakkarainen, 2004). DWR utilises designed tools that enhance interprofessionality and encourage a discursive space that enable diversity and dialogue to emerge (R. Engeström, 2014b; Y. Engeström \& Sannino, 2010). 
The family mediation service to be developed was to differ from the previous fragmented services; therefore, Fasper built the developmental work on social, psychological, therapeutic and judicial perspectives while working with parents in divorce. In 2009, the local authorities of six municipalities in Southern Finland granted the project written permission to research and develop their family mediation practices. The leaders of every involved agency and organization invited their staff members to engage in the project and all who decided to participate agreed with the research permission.

Social workers, child welfare supervisors, ${ }^{7}$ family workers, psychologists, family counsellors, attorneys and judges from different organizations (municipalities, churches, courts and private law firms) participated in the project. They were organized in two similarly-composed local learning networks that met separately every other month for two years. Every session, with an average of 14 participants per session, lasted approximately three hours and the two networks worked with similar learning tasks.

At the beginning of the sessions, the researcher-interventionists reminded the participants of the nature of Fasper as both a developmental and research project. They noted that the sessions were either audio- or video-taped for two purposes: for use as mirror-data (see Y. Engeström, 2007) or as data to research processes of learning and knowledge creation in developing family mediation. The gathered data would only be handled by the project researchers according to responsible conduct of research. All participants approved.

Between the sessions, the participants worked on learning tasks that were connected to the project and designed to serve the formation of a local family mediation service. Furthermore, both networks participated in two family mediation training 
workshops held by Lisa Parkinson, a British family mediator and family mediation trainer.

\section{The Study}

\section{Data of the Study}

I investigate the beginning of multi-professional and multi-organizational collaboration in two learning networks. My intention is to explore the diversity of ways to embody collaboration and learning in a boundary crossing setting, rather than to compare the two networks. As mentioned earlier, the research question is: How do the first steps towards collaboration and interprofessionality emerge and what kind of learning can be identified in the discussions between the participants during the initial meetings of the two studied learning networks?

My study concentrates on the very first sessions of both learning networks. The aim of this session was twofold: firstly, to introduce the participants to each other by sharing knowledge and secondly, to examine and begin to question the current state of family mediation in order to set a shared object of work for the network's forthcoming developmental collaboration.

The researcher-interventionists divided the participants into subgroups according to their work locations and occupations and we gave them two tasks: 1) To type and label divorcing parents in order to make visible to the participants the different occupational, professional and organizational approaches to their clients. From this point of view, typing clients was an intervention that aimed to reveal boundaries and enhance dialogue between the professions; and 2) To place the labelled types into a four-square matrix with two dimensions suggested by us researcher-interventionists (Figure 1). On the horizontal dimension, the subgroups evaluated how easy or difficult 
the conflict was for the diverse types of parents and on the vertical dimension how light or arduous the conflict was to handle for the practitioners. Subsequently, all participants examined together the outcomes of the work of the subgroups.

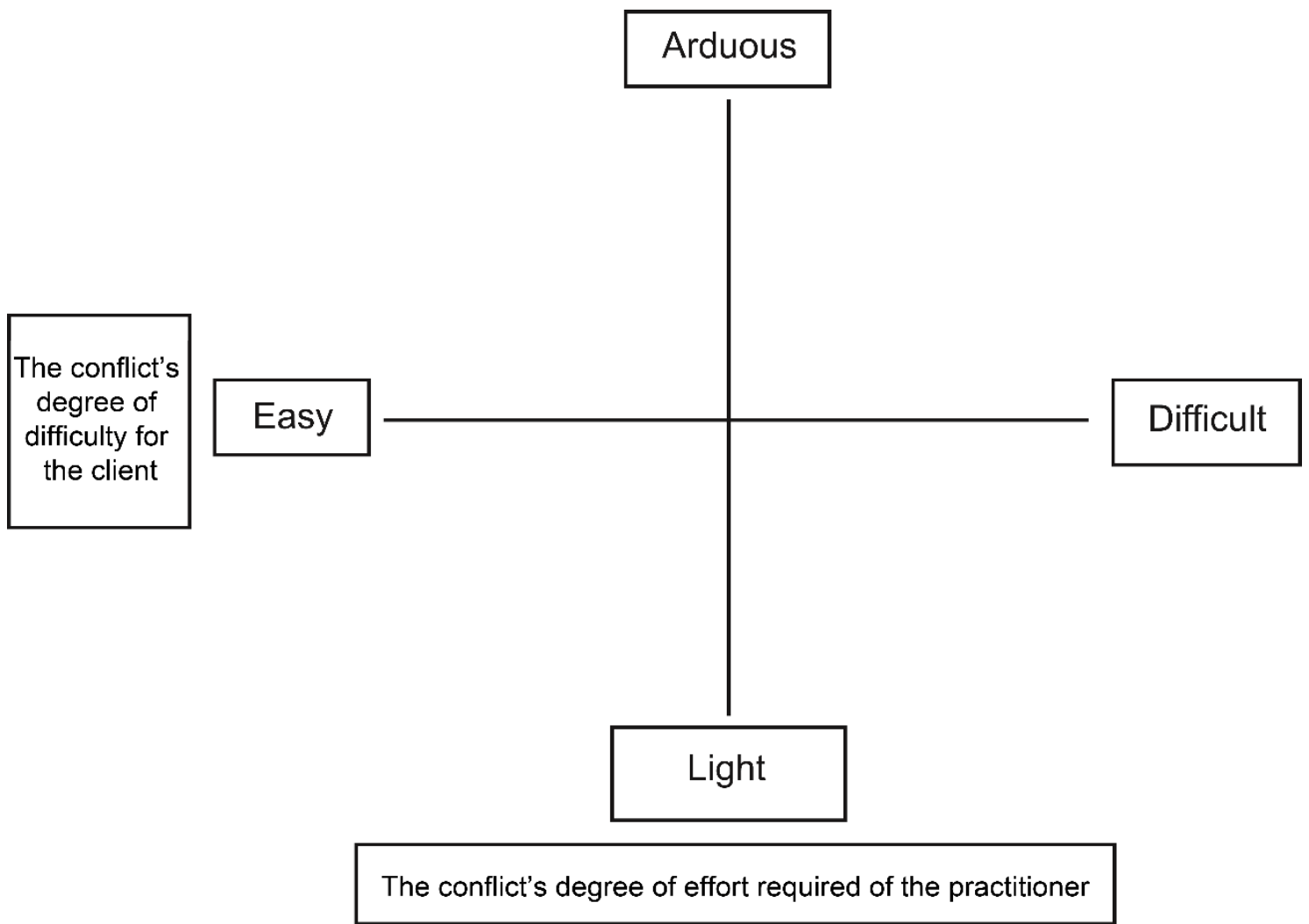

Figure 1. A four-square matrix for placing identified types of divorcing parents.

For the purpose of my study I have transcribed the audio-taped discussions during the first sessions of both learning networks on a turn-taking level including talk, laughter and pauses. Altogether, the naturally-occurring transcribed data consisted of 51 pages of text.

\section{Method of Analysis}

I ground my analysis of the transcripts in discourse analysis that understands discourse as an active process in using language (Hepburn \& Potter, 2004). My method was inspired by the theory of communicative projects (Linell, 2009; Luckmann, 1995) that 
focuses the analysis of discourse on the substance of the interaction for the participants and deals with both structural provisions and topicality as two simultaneous sides of discourse (Linell, 2009). The analysis centred on detecting communicative patterns in sequences of discourse. Additionally, it was oriented to detect disruptions in the sequences, such as dilemmas, conflicts or double binds, which could be interpreted as discursive manifestations of contradictions (Y. Engeström \& Sannino, 2011). The sequential findings were furthermore used to detect dialogical learning mechanisms.

\section{Results}

Both networks presented a vivid picture of the divorcing parents practitioners meet in their work. The participants divided parents into several types (task 1) describing client behaviour, need for help and motives. When they placed the types on the four-square matrix (see Figure 1), the participants found that working with most of the parents was challenging for them. They experienced these client cases as complex, demanding and even frustrating because they did not actually know how to assist the parents. The participants discussed the different types of parents very eagerly from their own professional points of view and focused on the ones that were placed in the difficult and arduous quadrant of the four-square matrix.

After quite similar discussions on the types of the parents in the two learning networks, the discussions gained a different focus. One network concentrated on the clients, whereas the other directed the attention towards the activity of the service system. Accordingly, I named these the client-centred and the service system-centred network.

\section{The Client-Centred Network}

The discussion in the client-centred network focused on the clients, their needs and 
behaviour. The practitioners noted that they had clients in common, but that they described them differently, had different perspectives on them and were guided by different laws. The following excerpt ${ }^{8}$ gives an example of a child welfare supervisor's view:

It is obvious that those clients we have are really the same families; we just label them differently. [we realize that] they visit all of us and ... poor clients: we have different laws and different perspectives.

The participants expressed that they benefitted from becoming acquainted with each other's diverse practices and approaches. The different ways of dividing the parents into types helped them understand how others work; as one psychologist noted:

... this [group of] child welfare supervisors and attorneys, just said it so well, that they have to come to a clear solution, while we sometimes strive for a short period [of contact] with distinct processes, but often we go quite far and deep into the matters. The work we do is very different; we work with recovery processes while the aim of their group is to get an agreement that will give a structure to life after divorce.

When discussing practices, they emphasised the division of labour between them, showing the boundaries of their own professions (cf. Kerosuo, 2004, 40).

The talk at the boundary to recognize a shared problem space was quite congenial. One participant disrupted the talk by telling an anecdote about a success in court due to a judge changing his way of working when resolving a dispute between parents. With this anecdote the narrator stated that there was a need for new ways to work and that some kind of enforcement or obligation is needed to make new forms of multi-agency work viable. By telling what the judge did differently, the narrator gave an example of what methods could be used. 
Eventually, the participants conceded that all the diverse types could be divided consistent with the typology originally suggested by a subgroup of legal practitioners. This typology divided all divorcing parents by four different main focuses in their conflict: child-centred, money-centred, self-centred or relationship-centred, the last of which meant that the parents, although divorced, were unable to disconnect from their relationship. The participants additionally agreed that all the types of parents placed in the arduous and difficult quadrant of the four-square matrix could, in fact, be included in the 'relationship-centred' type of parents. The participants came to a conclusion: since the families are so different and the difficulties stem from this relationship centeredness of the parents, every practitioner works well enough with his or her own part of the difficulties. The status quo should be preserved since it functions acceptably.

The analysis detects two emerging dialogical learning mechanisms during this first session: Identification (by typing parents the participants came to comprehend their own work in relation to that of the others) and Coordination (establishing routines for maintaining the division of labour). Transformation requires confrontations and some attempts to confront—such as telling the anecdote-were made in this network. The confrontations remained attempts, however, and led to no further dialogue. The following pattern for the communicative activity (Linell, 2009) during this first session shows how the flow of the dialogue stops and closes: presenting $\rightarrow$ agreeing $\rightarrow$ confronting $\rightarrow$ dismissing by explaining one's own view or digressing $\rightarrow$ agreeing $\rightarrow$ presenting $\rightarrow$ confronting $\rightarrow$ dismissing by remaining silent and digressing. The members of the network began to form a view of their shared problem space; however, they did not question the present situation.

\section{The Service System-Centred Network}

The participants of the service system-centred network also recognised that the parents 
use all available services; therefore, they have clients in common. Differing from the practitioners in the client-centred network, they concentrated their discussion on the distributed system of providing services that appeared scattered and confusing to both them and the parents. They placed many types in the difficult and arduous quadrant, but the focus of the discussion turned to how to prevent the divorcing parents from becoming a difficult and challenging case.

The participants introduced a metaphor, 'the funnel', and visualised it on a flipchart (Figure 2). Most of the discussion concerned this funnel: its organization, parental access and the arrangements that could be made so that parents and their children could "stay alive and healthy" through the funnel. The funnel was further developed into a systemic model of their shared problem space and became a tool for collaboration. The participants began to envision a new, different way of working with the same clients.

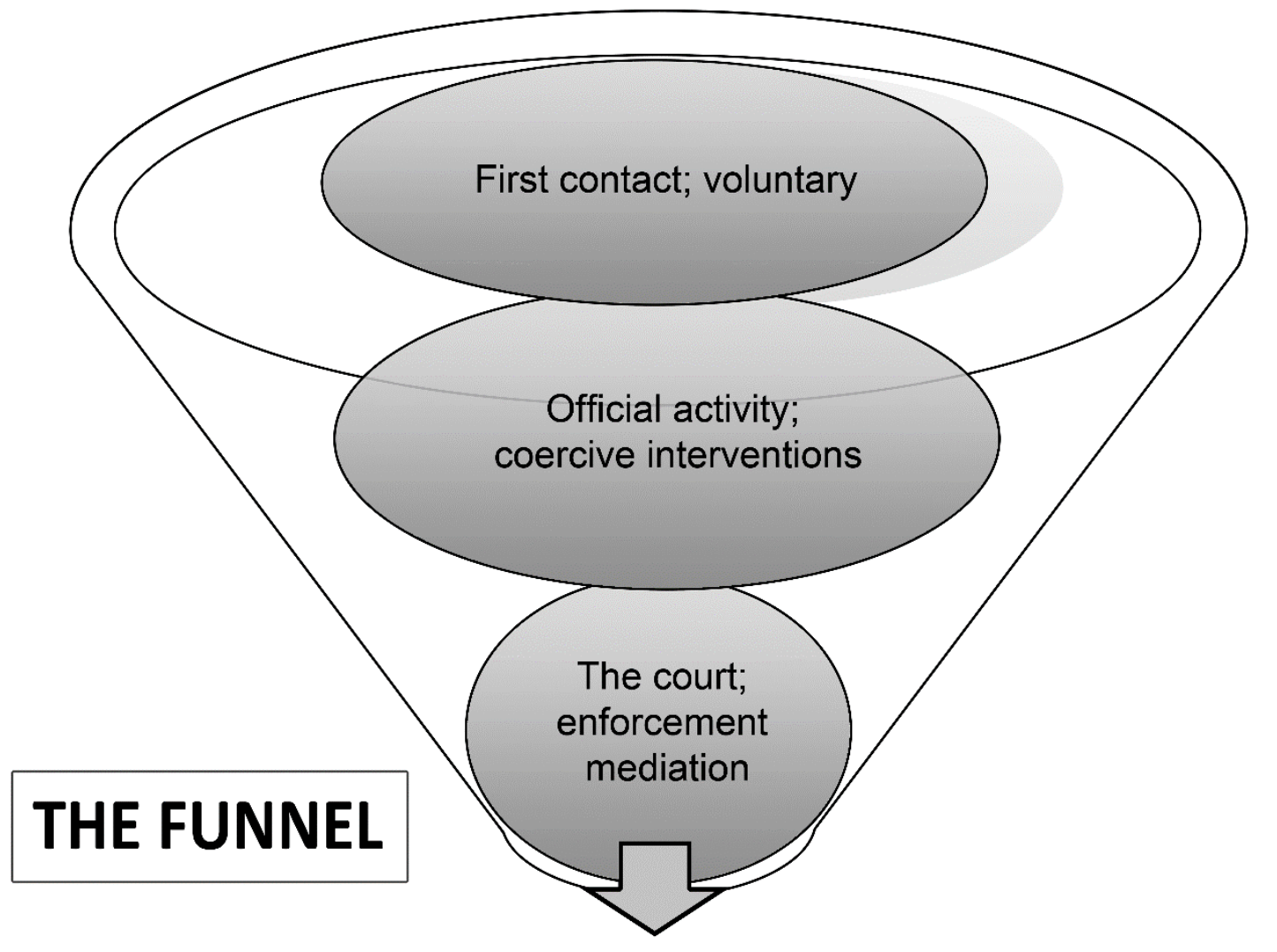

Figure 2. The funnel, a model created by the service system-centred learning network. 
In this network the talk at the boundary to recognize a shared problem space was intense. Even though the participants seriously questioned each other's practices, they did not defend their positions. Instead, they made further suggestions that enriched the shared view. An invitation to joint efforts could begin with one practitioner guessing what some of the others do and where the services they represent could be placed in the funnel. The excerpt below reflects a family counsellor trying to grasp the service system by guessing and inviting the others to collaborate.

I don't know, maybe the funnel could be divided in three parts. In the middle there could be some social work and child protection services and then I imagine that our [family counselling] services could be on the top. And on the top there are lots of different, I don't know what to call them, maybe child first [because the symptoms of the child cause the contact to the services] or family services? And in the middle those social kinds of services. And when they [the parents] quarrel they go to the child welfare supervisor, or? I don't really know this very well; you may know much better; tell me.

Confrontation and recognizing a shared problem space are characteristic processes of boundary crossing implying Transformation (Akkerman \& Bakker, 2011). Such processes evolved in the discussion during this first session and resulted in the collaboratively created funnel model - a first conceptualization of a shared problem space. The funnel functioned as a tool that mediated a shared understanding of the present and envisioned better future collaboration.

A typical pattern for the communicative activity (Linell, 2009) is the following: confrontation $\rightarrow$ softening $\rightarrow$ solving $\rightarrow$ motivating $\rightarrow$ solving $\rightarrow$ answering and dismissing $\rightarrow$ repeating solution $\rightarrow$ enriching and clarifying $\rightarrow$ and suggesting a metaphor. The pattern shows that in this network, unlike in the other, confrontations do not lead to disruptions, but rather are further discussed and the dialogue continues. 


\section{Discussion}

The analysis detected emerging dialogical learning mechanisms (Akkerman \& Bakker, 2011) in discussions during the first sessions of the two studied learning networks. The networks resembled each other and accomplished similar tasks; nonetheless, they differed according to which learning mechanisms emerged as processes and carried dialogue. The participants labelled types of divorcing parents and this helped them understand their own practices in relation to those of the others, which is a characteristic of Identification. This resonates with Edwards' (2011) findings: in their use of categorizations, practitioners reveal the meanings of their practices. These categorizations mediate understanding of the practices in which they arise and help other practitioners to develop a professional multilingualism that will allow them to negotiate across boundaries (Edwards, 2011).

Coordination establishes continuity, facilitates effortless moving between different sites in the future and has a potential to overcome boundaries (Akkerman \& Bakker, 2011). In both networks Coordination emerged, but in the client-centred network they focused more on it for crossing boundaries than in the other.

In the service-system centred network, the funnel, first introduced as a metaphor and then further developed into a model, grew out of the practitioners' own discussions containing Reflection (perspective making and perspective taking). Models such as the funnel are needed to describe complexities, which cannot be collaboratively considered based on distinct professional epistemologies (cf. Toiviainen, Kerosuo \& Syrjälä, 2009). It can also be interpreted as a boundary object (Star \& Griesemer, 1989), a communal tool for translation between intersecting practices.

Transformation leads to profound changes in practices; sometimes even totally new ones are devised. Transformation requires confrontation with some lack or problem 
that forces the intersecting worlds to seriously reconsider their current practices and interrelations (Akkerman \& Bakker, 2011). In both networks confrontations arose, but they were met differently, which is shown by analysing both the communicative patterns and the content of the discussions. In the client-centred network, confrontations were avoided and the dialogue closed. An example of this is the confronting anecdote, that could be labelled a 'second story' (Ryave, 1978), which is a safe way of bringing in ideas that might challenge the current situated narrative (Edwards, 2010, 146). It held the potential of beginning the questioning of the present and envisioning of the future, but it was bypassed and functioned more to preserve the status quo (cf. Edwards, 2011). In contrast, the participants of the service system-centred network used confrontations to explore and promote dialogue. Together they created the funnel that functioned as a tool for discursive collaboration and questioned the present state of the service system. It visually conceptualized the need state of the network and structured the shared problem space. Additionally, the participants began to cautiously envision the future. The joint construction of the funnel metaphor indicates that the participants moved towards interprofessionality.

Metaphors, anecdotes, and models are discursive tools with power to overcome boundaries and they can be understood even though the participants come from different occupations, professions and organizations. They are tools participants may use and also create themselves, but they will not necessarily enter into exploring each other's understandings, which was observed in the client-centred network. Instead there is a need to actively create new tools for collaboration and focus on the participants' recognition of boundaries to be crossed in order to enter a new fruitful discursive space (Akkerman, Admiraal, Simons, \& Niessen, 2006; R. Engeström, 2014a). A better 
understanding of learning in multi-professional intersecting groups can be reached by observing and analysing discursive tools.

Both the networks began to identify a shared problem space, which is a characteristic process of boundary crossing in Transformation. In the client-centred network they started to form a view of their shared problem space but did not, however, question the present situation. The participants concluded that the parents are individuals with individual needs; therefore, the practitioners decided to continue to work as before. Eventually, the work will improve due to new acquaintance with each other's work and coordination of tasks. This pattern of speech led to preserve the current activity without boundary crossing and opening dialogue for developing new ideas and solutions. My interpretation is that the participants did not actually recognise a shared problem space, even though they recognised that they shared clients.

The participants in the service-centred network focused on the service system and its failure to meet the needs of the divorcing parents in conflict. They recognized this scattered service system, conceptualized as the funnel, as their shared problem space in need of change. The funnel possessed three major functions: It was 1) a conceptualization of the shared problem space; 2) a tool for collaboration; and 3) the conceptualization of a shared object of work of the intersecting practices. In this sense, the funnel expresses an example of the threefold nature of a situated artefact that forms the core of new knowledge practices (Paavola, R. Engeström, \& Hakkarainen, 2012, p. 2).

The funnel as the conceptualization of a shared object of work of the intersecting practices had the potential to become an epistemic object to the participants. Following Knorr-Cetina (2001), epistemic, or knowledge-objects are incomplete, open-ended, never fulfilled and more distant in time than goals. This changing, unfolding character 
of epistemic objects emotionally binds experts to them. Participants sharing such relation to the epistemic object — they are engrossed and excited by it—will also be in a relation to each other. This relation will be characterized by mutual respect, willingness to share expertise and to listen to, reflect upon and respond to the knowledge of the others (Knorr-Cetina, 2001; cf. relational agency, Edwards, 2010).

Furthermore, the service system-centred network collaboratively built new understandings of their shared problem space. The funnel indicates a step towards interprofessionality: it represents new shared knowledge constructed together and is a result of genuine inter-professional collaboration. In contrast, the whole meeting in the client-centred network resulted in a joint understanding of the divorcing parents based on a typology originally made by the subgroup consisting of those with legal expertise. From the perspective of learning and interprofessionality, this network was not, at this moment, able to move forward from the typology. Instead, they adopted, without further developing, the understanding of one subgroup and accepted this interpretation of their shared problem space as valid. This session, however, was only the first of many, and both learning networks continued the collaborate developmental work.

\section{Conclusion and Further Implications}

There are ontological, epistemological and ethical reasons for inter-professional collaboration (Wackerhausen, 2009), which becomes a pragmatic response on managing multi-faceted and complicated problems (Couturier et al., 2008) of the knowledge society (Nowotny, Scott, \& Gibbons, 2001) and social work today. Inter-professional collaboration advances learning and promotes change (Akkerman \& Bakker, 2011). The disappointments of and difficulties in multi- and inter-professional collaboration can be due to the confusion about what kind of collaboration is needed or set as a goal. It is also correct, however, that collaboration may be a waste of resources if the objects of 
work do not require it (McLaughlin, 2013). Nonetheless, when needed, collaboration crossing professional and organisational boundaries may solve complex problems and promote learning and innovation.

The two networks in my study started the collaborate journey towards developing family mediation diversely. The result indicates that although the collaboration may get a flying start, the opposite is also possible. Therefore, both discursive tools and the opportunity to work together for a longer period of time are needed. Interprofessionality, the meeting of differing worlds of knowledge, is a personal challenge to everyone participating as it affects identity and professional identities are being negotiated alongside expertise (Edwards \& Kinti, 2010). McLaughlin (2013) also expresses a worry concerning multi-professional work: is it possible that interprofessional work can result in deprofessionalisation and the creation of a new kind of (non)professional? Edwards (2010), however, points out that the relational turn in expertise does not mean eroding identities, but rather the emergence of a new, additional form of relational expertise and agency. Relational agency requires that practitioners, on the one hand, are able to recognize and draw on the expertise that is distributed across networks, and, on the other, contribute to it; however, they must hold a core expertise in their own field to be able to contribute (Edwards, 2010; 2011).

The sites of intersecting practices are social worlds in-between (both/and phenomena) the practices, but they simultaneously belong to neither one nor the other. Engagement at these boundaries does not involve a fusion of the intersecting practices. Maintaining uniqueness and professional identities is a characteristic process of boundary crossing crucial to Transformation (Akkerman and Bakker, 2011). In order to emphasize the unique characteristics of this 'figured world' (Holland, Lachicotte, Skinner \& Cain, 1998) at the intersection, I propose the term intersectional world. In the 
intersectional world the activities of the partaking worlds, but not the diverse and specific professional expertise, are partly integrated. The new knowledge created by the inhabitants of this world is intersectional; it is an outcome of polycontextual expertise (Y. Engeström et al., 1995) and transformative agency (R. Engeström, 2014a) of individuals transforming their 'collectividual' practices (Stetsenko, 2013). A longitudinal perspective may show how new identities form through negotiation.

To better understand the differences in learning networks, the role of individual agency in activities should be examined. In my study, the two networks were occupationally and organizationally quite similarly composed and the work during the first session was guided by the same tasks (interventions), yet they advanced diversely. A transformative learning process is not collective in a generalized holistic sense, but in the sense of participation where individual participants position themselves as learners (R. Engeström, 2009). To understand this, we need to pose questions like: Did the participants of the study diverse in former experiences of participating in activities similar to the learning networks of Fasper? How do participants conceptualize learning and how does this influence their participation and engagement in the work of the networks? Participants may not share the same meanings in relation to activities, but they do share their subjectively unique understandings of their participation (R. Engeström, 2009, 2014a; Valsiner, 2001). A further challenge for research is to explore the participants' own agency that challenges and resists community practices.

Social work education, like the education in other professions, emphasizes a solid and specific knowledge base and competence. Education constructs boundaries against other professions; however, complex problems need solutions including perspectives from many and various occupations and professions. When boundaries are recognised as resources for learning, social work education should also include work 
and dialogue on boundaries. Education faces a challenge: How can education on the one hand generate a solid specific professional competence and, on the other, concurrently develop an ability to reflect upon work or the problems at hand from diverse perspectives and find the object of work together with other professional practitioners? To manage this challenge to build boundaries, but learn to overcome them, should be an essential part of social work education.

It is a demanding task for education and work to create opportunities for participation and collaboration across a diversity of sites both within and across institutions and organizations (Akkerman \& Bakker, 2011). We inevitably need interprofessionality, especially when we develop work or activities, that do not traditionally belong to any profession. This was the case concerning family mediation in Finland. In my study developing inter-professional family mediation practices served as an example of a solution to a complex problem: divorcing parents in conflict could not find the help they needed and the practitioners did not know how to assist. From this point of view, the findings can be generalized to other contexts where interprofessionality is required. The findings also reveal the dilemma of building and overcoming boundaries mentioned above as a focal challenge for social work education.

\section{References}

Akkerman, S.F., \& Bakker, A. (2011). Boundary crossing and boundary objects. Review of Educational Research, 81, 132-169. doi:10.3102/0034654311404435

Akkerman, S., Admiraal, W., Simons, R.J., \& Niessen, T. (2006). Considering diversity: Multivoicedness in international academic collaboration. Culture \& Psychology, 12, 461-485. doi:10.1177/1354067X06069947

Alasoini, T. (2011). Learning networks as an infrastructure for the creation and dissemination of workplace innovation: An introduction. In T. Alasoini, M. Lahtonen, N. Rouhiainen, C. Sweins, K. Hulkko-Nyman, \& T. Spangar (Eds.), Linking theory and practice: Learning networks at the service of workplace 
innovation (pp. 13-30). Helsinki: Tekes. Retrieved from http://www.tekes.fi/globalassets/julkaisut/75_linking_theory_and_practice.pdf

Bessant, J. \& Tsekouras, G. (2001). Developing learning networks. AI \& Society, 15, 82-98. Doi:10.1007/BF01205739

Couturier, Y., Gagnon D., Carrier, S., \& Etheridge, F. (2008). The interdisciplinary condition of work in relational professions of the health and social care field: A theoretical standpoint. Journal of Interprofessional Care, 22, 341-351. doi:10.1080/13561820802190616

Edwards, A. (2010). Being an expert professional practitioner. The relational turn in expertise. London: Springer.

Edwards, A. (2011). Building common knowledge at the boundaries between professional practices: Relational agency and relational expertise in systems of distributed expertise. International Journal of Educational Research, 50, 33-39. doi:10.1016/j.ijer.2011.04.007

Edwards, A., \& Kinti, I. (2010). Working relationally at organisational boundaries: Negotiating expertise and identity. In H. Daniels, A. Edwards, Y. Engeström, T. Gallagher, \& S.R. Ludvigsen (Eds.), Activity theory in practice: Promoting learning across boundaries and agencies (pp. 126-139). London: Routledge.

Engeström, R. (2009). Who is acting in an activity-system? In A. Sannino, H. Daniels, \& K. Gutiérrez (Eds.), Learning and expanding with Activity theory (pp. 257273). New York: Cambridge University Press.

Engeström, R. (2014a). New forms of transformative agency. In A. Littlejohn \& A. Margaryan (Eds.), Technology-enhanced professional learning: Processes, practices and tools (pp. 59-70). New York: Routledge.

Engeström, R. (2014b). The interplay of developmental and dialogical epistemologies. Outlines: Critical Practice Studies, 15, 119-138. Retrieved from http://ojs.statsbiblioteket.dk/index.php/outlines/article/view/16834/14611

Engeström, Y. (1987). Learning by expanding. An Activity theoretical approach to developmental research. Helsinki: Orienta-konsultit.

Engeström, Y. (2007). Putting Vygotsky to work: The change laboratory as an application of double stimulation. In H. Daniels, M. Cole, \& J.V. Wertsch (Eds.), The Cambridge companion to Vygotsky (pp. 363-382). New York, NY: Cambridge University Press. 
Engeström, Y., Engeström, R., \& Kerosuo, H. (2003). The Discursive Construction of Collaborative Care. Applied Linguistics, 24, 286-315. Retrieved from https://www.helsinki.fi/content/24/3/,DanaInfo=applij.oxfordjournals.org+286

Engeström, Y., Engeström, R., \& Kärkkäinen, M. (1995). Polycontextuality and boundary crossing in expert cognition: learning and problem solving in complex work activities. Learning and Instruction, 5, 319-336. doi:10.1016/09594752(95)00021-6

Engeström, Y., \& Sannino, A. (2011). Discursive manifestations of contradictions in organizational change efforts: A methodological framework. Journal of Organizational Change Management, 24, 368-387. doi:10.1108/09534811111132758

Engeström, Y., \& Sannino, A. (2010). Studies of expansive learning: Foundations, findings and future challenges. Educational Research Review, 5, 1-24. doi:10.1016/j.edurev.2009.12.002

Haavisto, V., Bergman-Pyykkönen, M., \& Karvinen-Niinikoski, S. (2014). Perheasioiden sovittelun uudet tuulet. Havaintoja, mallinnuksia ja arvioita Fasper-hankkeen pohjalta. [Novelties in family mediation. Observations, models and evaluations from the project Fasper.] Helsinki: Suomen sovittelufoorumi.

Hepburn, A., \& Potter, J. (2004). Discourse analytic practice. In C. Seale, G. Gobo, J.F. Gubrium, \& D. Silverman (Eds.), Qualitative Research Practice (pp. 180-196). London: Sage.

Holland, D., Lachicotte, W. Jr., Skinner, D., \& Cain, C. (1998). Identity and agency in cultural worlds. Cambridge, MA: Harvard University Press.

Hämäläinen, J. (2012). Huoltoriitojen kustannukset yhteiskunnalle: taloudellisen arvioinnin teoreettisia ja metodologisia haasteita. [Public costs of disputes over child custody: theoretical and methodological challenges of economic valuation.] In A. Kääriäinen, J. Hämäläinen, \& P. Pölkki (Eds.). Eron haasteet, väliintulot ja lapset. Challenges of divorce, interventions and children. (pp. 213-241). Helsinki: Ensi- ja turvakotienliitto.

Julkunen, I. \& Karvinen-Niinikoski, S. (2014). Socially robust knowledge processes of local and global interest in social work. In T. Harrikari, P.-L. Rauhala, \& E. Virokannas (Eds.), Social change and social work: The changing societal conditions of social work in time and place. (pp. 101-120). Farnham: Ashgate. 
Kerosuo, H. (2004). Examining boundaries in health care: Outline of a method for studying organizational boundaries in interaction. Outlines, 6(1), 35-60. Retrieved from http://ojs.statsbiblioteket.dk/index.php/outlines/article/view/2149/1894

Klein, J. T. (1996). Crossing boundaries: Knowledge, disciplinarities and interdisciplinarities. Charlottesville: University Press of Virginia.

Knorr-Cetina, K. (2001). Objectual practice. In T.R. Schatzki, K. Knorr-Cetina, \& E. von Savigny (Eds.), The Practice Turn in Contemporary Theory (pp. 175-188). London: Routledge.

Linell, P. (2009). Rethinking language, mind, and world dialogically: Interactional and contextual theories of human sense-making. Charlotte, NC: Information Age Publishing.

Luckmann, T. (1995). Interaction planning and intersubjective adjustment of perspectives by communicative genres. In E.N. Goody (Ed.), Social intelligence and interaction: Expressions and Implications of the Social Bias in Human Intelligence (pp. 175-186). Cambridge: Cambridge University Press.

Mattila-Aalto, M., Bergman-Pyykkönen, M., Haavisto, V., \& Karvinen-Niinikoski, S. (2012). Konfliktiteoreettinen näkökulma eroihin ja palvelujen kehittämiseen. [A conflict-theoretical perspective on divorce and service development.] In A. Kääriäinen, J. Hämäläinen, \& P. Pölkki (Eds.). Eron haasteet, väliintulot ja lapset. Challenges of divorce, interventions and children. (pp. 213-241). Helsinki: Ensi- ja turvakotienliitto.

McIntosh, J. (2003) Enduring conflict in parental separation: Pathways of impact on child development. Journal of Family Studies, 9, 63-80. doi:10.5172/jfs.9.1.63

McLaughlin, H. (2013). Motherhood, Apple Pie and Interprofessional Working. Social Work Education, 32, 956-963. doi:10.1080/02615479.2012.709841

Nowotny, H., Scott, P., \& Gibbons, M. (2001). Re-thinking Science: Knowledge and the public in an age of uncertainty. Malden, MA: Polity Press.

Paavola, S., Engeström, R., \& Hakkarainen, K. (2012) The trialogical approach as a new form of mediation. In A. Moen, A. I. Mørch, \& S. Paavola (Eds.) Collaborative knowledge creation: Practices, tools, concepts (pp. 1-14). Rotterdam: Sense Publishers. 
Paavola, S., Lipponen, L., \& Hakkarainen, K. (2004) Models of innovative communities and three metaphors of Learning. Review of Educational Research, 74, 557-576. doi:10.3102/00346543074004557

Ryave, A. L. (1978). On the achievement of a series of stories. In J. Schenkein (Ed.). Studies in the Organization of Conversational Interaction (pp. 113-132). New York: Academic Press.

Star, L. S. \& Griesemer, J. R. (1989). Institutional ecology, 'translations' and boundary objects: Amateurs and professionals in Berkeley's Museum of Vertebrate Zoology, 1907-39. Social Studies of Science, 19, 387-420. doi:10.1177/030631289019003001

Stetsenko, A. (2013). The challenge of individuality in Cultural-Historical Activity Theory: "Collectividual" dialectics from a transformative activist stance. Outlines: Critical Practice Studies, 14(2), 7-28. Retrieved from http://ojs.statsbiblioteket.dk/index.php/outlines/article/view/9791

Toiviainen, H., Kerosuo, H. \& Syrjälä, T. (2009). "Development Radar": the coconfiguration of a tool in a learning network. Journal of Workplace Learning, 21, 509-524. doi:10.1108/13665620910985513

Valsiner, J. (2001). Process structure of semiotic mediation in human development. Human Development, 44, 84-97. doi:10.1159/000057048

Wackerhausen, S. (2009). Collaboration, professional identity and reflection across boundaries. Journal of Interprofessional Care, 23, 455-473. doi:10.1080/13561820902921720

Acknowledgements: The writer wants to thank Professor Synnöve Karvinen-Niinikoski and $\mathrm{PhD}$, Senior Researcher Ritva Engeström at the University of Helsinki, and PhD Vaula Haavisto for invaluable comments during the process of writing this article. The writing of this paper was funded by stipendiary support to the writer from Waldemar von Frenckells Stifelse, The Ella and Georg Ehrnrooth Foundation and The Finnish Work Environment Fund.

No potential conflict of interest is reported by the author. 


\section{Notes}

${ }^{1}$ A learning network for long-term interaction is established for the primary purpose of generating learning events and creating innovation potential. Participants with a sufficiently broad diversity of expertise and a shared interest in adequately similar development issues meet as learners to contribute expertise and ideas allowing the others to utilise and benefit from them. All the participants are learners (Alasoini, 2011; Bessant \& Tsekouras, 2001).

${ }^{2}$ Y. Engeström, R. Engeström and Kerosuo (2003) observe that the objects are not the same as goals that are primarily conscious, relatively short-lived and finite aims of individual actions. The object is a heterogeneous and internally contradictory, yet enduring, constantly reproduced purpose of a collective activity system (here-learning networks) that motivates and defines the horizon of goals and actions (Y. Engeström et al., 2003).

${ }^{3}$ Hereafter, when I refer to these dialogical learning mechanisms, I spell the concepts beginning with a capital letter.

${ }^{4}$ Fasper (abbreviation for the Finnish words for facilitative family mediation: fasilitatiivinen perhesovittelu) was initiated and organized by the Finnish Forum for Mediation, a nongovernmental organization dedicated to promote mediation as an alternative conflict resolution in for example workplaces and schools. The project was funded by Finland's Slot Machine Association, whose funding operations are governed and monitored by the Ministry of Social Affairs and Health (MSAH), and realized in partnership with and scientifically supervised by faculty in the discipline of social work at the University of Helsinki.

${ }^{5}$ Hereafter, I use only the term divorce for short. With the term I mean both separation and divorce and separating/separated and divorcing/divorced parents. The focus of the project described in this article was not on the legal aspects of separation and divorce but on the changing roles in parenthood.

${ }^{6}$ The following phases constitute the ideal-typical cycle of expansive learning: questioning and analysing the present activity, modelling the new activity; experimenting; implementing; consolidating; evaluating and reflecting. (For a presentation of the model and studies in which it has been used, see e.g., Y. Engeström \& Sannino, 2010).

${ }^{7}$ In Finland child welfare supervisors (or officers) are social workers or lawyers by training and they work in municipalities. They register parents' agreements on the custody and maintenance of their children after divorce. Additionally, they administer the confirmation of paternity.

${ }^{8}$ The translations of the excerpts are all my own. 